\title{
Memories from the Darkness in the Films of Pedro Costa and Affonso Uchôa
}

This essay analyses realist works from contemporary world cinema wherein the representation of space-time is directly affected by the color black, referring to both night and dark shadows. It investigates exactly how darkness participates in moments when the filmed subjects remember traumatic events and confront them through their courageous retellings. My hypothesis is that the color black converts the space-realistic and concerning the characters' present time-into a place where different temporalities coexist. Through a comparative analysis of films made by the Portuguese filmmaker Pedro Costa and the Brazilian filmmaker Affonso Uchôa in the past two decades, I show how this modulation in space-time produced through color has a political meaning, since the narrated memories are related to a social experience of class and race.

Keywords

FILM AESTHETICS

POLITICS

COLOR

BLACK

DARKNESS

MEMORY

SPACE

TIME

Date submitted: 29/4/2021

Date accepted: $23 / 9 / 2021$

Edson Costa Júnior

jredsoncosta@gmail.com

orcid.org/0000-0001-8523-8664

Edson Costa Jr. is currently a postdoctoral fellow at Unicamp Arts Institute, with a grant from FAPESP

(21/02448-5). He has a doctorate in Media and Audiovisual Processes from the School of Communication and Arts at the University of São Paulo (USP), with funding from FAPESP, and was a visiting student researcher at Université Sorbonne Nouvelle - Paris 3. He completed a postdoctoral fellowship at the Department of Fine Arts at USP (2018-2021) with a grant from the National Postdoctoral Program/CAPES. 


\section{Introduction}

The use of long takes as a realist method to film a "succession of concrete instants of life"1-ordinary events that are apparently devoid of any dramatic role-has been a constant in contemporary world cinema. Such a choice generally pairs a nearethnographic interest in the quotidian with the desire to restore a trace of phenomenal reality of the world to image and sound. In recent years, a range of scholars have highlighted the prominence of the corporal meaning/ perception of the in-scene subjects with this realist aesthetic. Among them, Thomas Elsaesser (2009) identifies the recurrence of characters in contemporary transnational films whose experience with the world is mediated by restricted or augmented sensorial capacities, abnormal psychologies, pathologies, or postmortem situations. According to Elsaesser, the externalization or reallocation of the consciousness or subjective states of such characters through the world of "things" (objects that they handle, spaces they inhabit) directly affects the space-time coordinates of a narrative, and as a result, the viewer's reception-the viewer is invited to readjust their presuppositions and perception of the diegetic universe. ${ }^{2}$

My essay traces this articulation between a realist aesthetic regime and a representation of space and time as categories modulated according to the experience of the filmed subjects. I hope to contribute to the discussion by approaching it from an angle situated between the fields of aesthetics and politics. To be more precise, I will investigate examples from contemporary world cinema wherein the space-time axis is affected by the color black, understood here as being from the perspective of illumination. I refer to works whose predominance of the color black in the represented space is the result of night scenes and, in general, from the existence of dark shadows. I am interested in examining how the darkness derived from such a configuration coincides with moments when the characters narrate a social experience, remembering and confronting a traumatic past with their words and testimonies. My hypothesis is that in these conditions darkness converts the space-which is realistic and linked to the characters' present time -into a place that welcomes the coexistence of multiple temporalities.

The capacity that I attribute to the color black to interfere in space and, thus, time corresponds to the ideas of Gilles Deleuze, specifically in his understanding that shadows "[potentialize] space, whilst making it something unlimited," at the same time that they determine "virtual conjunctions which do not coincide with the state of things or the position of characters which produce it" (Deleuze 1986, 112). Shadows are one of the three means of production of what his then-student, Pascal Auger ${ }^{3}$ calls espace quelconque ("any-space-whatever"). The other two are lyrical abstraction, defined by the relation of light to white, and image-color. The following is one of the definitions of the concept:

Any-space-whatever is not an abstract universal, in all times, in all places. It is a perfectly singular space, which has merely lost its homogeneity, that is, the principle of its metric relations or the connection of its own parts, so that the linkages can be made in an infinite number of ways. It is a space of virtual conjunction, grasped as pure locus of the possible. What in fact manifests the instability, the heterogeneity, the absence of link of such a space, is a richness in potentials or singularities which are, as it were, prior conditions of all actualisation, all determination. (Deleuze 1986, 109) 
Though it is relevant to the topic discussed in this essay, I will resist the temptation to apply Deleuze's concept. First, in contrast to Deleuze, I consider that some of the shadows take on an aspect of color-which I will explain in the following section. ${ }^{4}$ The second and more important reason for my resistance to a direct application of the espace quelconque is because it is capable of eliminating what happened in it, enabling it to become independent of the relations and orientations that give it to the characters. This independence is not present in the works that I analyze, in which the spatial color cannot be separated from the social experience of the in-scene subjects. Additionally, the use of the espace quelconque in contemporary films would demand a complex and anachronistic articulation that, I believe, would draw me away from my primary objective with this article.

I will defend my hypothesis of a modulation of space-time driven by the color black in certain works of realist contemporary cinema using a comparative analysis of the films of two filmmakers: the Portuguese filmmaker Pedro Costa and the Brazilian filmmaker Affonso Uchôa. Created from and about the social experiences of poor individuals and communities, their works also share connections in the way they couple aesthetics, including the artistic potential of the image, with politics. I will discuss Costa's In Vanda's Room (No quarto da Vanda, 2000) and Horse Money (Cavalo Dinheiro, 2014) and Uchôa's Seven Years in May (Sete Anos em Maio, 2019). In these films, it is important to stress, beyond the types cast previously by Elsaesser (2009), what is in question is the sociohistorical condition of the character-the subject-and not so much their sensorial capabilities.

As regards Pedro Costa's work, the transversal and heterogeneous presence of darkness and the color black has been the object of analysis for authors such as João Bénard da Costa (2009), who addressed the topic beginning with Costa's first featurelength film, Blood (Sangue, 1989), and extending to Colossal Youth (Juventude em Marcha, 2006). I will address the same subject but from a unique basis. My focus is related to the color black as the characters' memory, something that appears at points in In Vanda's Room, but that becomes, as I propose, crucial to the meaning conferred on the contrasts between light and shadow in Horse Money. In the latter film there is a palpable change in the lighting. According to Leonardo Simões (2015), the director of photography, while in Colossal Youth there was the possibility of working with natural light in combination with mirrors, metallic surfaces, and other reflective objects, in Horse Money the prevalence of interior settings and spaces with insufficient lighting required projected lights and even a small generator.

Affonso Uchôa, whose cinematic influences include the work of Pedro Costa (Uchôa 2020), represents a new generation of Brazilian filmmakers, with a filmography concentrated in the last decade. Though the night was of occasional importance in his prior film, Araby (Arábia, 2017, co-directed by João Dumans), Seven Years in May takes the expressive power of darkness a step further. Entirely nocturnal, the film joins the visual choices with the verbal testimony of a marginalized young Black man who was tortured by the police. The work was released at the end of the 2010s, the same period in which a variety of other Brazilian films used the night and the color black to give shape to a political position, including: Tell this to those who say we've been defeated (Conte isso àqueles que dizem que fomos derrotados, Pedro Maia de Brito, Cristiano Araújo, Camila Bastos, Aiano Bemfica, 2018); Dazed Flesh (Vaga carne, Grace Passô, 
2019), Tremor lê (Elena Meirelles, Lívia de Paiva, 2019); and Republic (República, Grace Passô, 2020). ${ }^{5}$

Although my concerns are directly related to the cinematography of Costa's and Uchôa's films, my interest is less about how the darkness is produced and more about the meaning that it engenders in the works. In a complementary sense, it is important to distinguish that the focus on the color black as a result of the lighting carries implications for the topic of race. Directed by white filmmakers, ${ }^{6}$ the films that constitute our object of analysis star marginalized Black subjects ${ }^{7}$ from countries-Cape Verde in Costa's case, and Brazil in Uchôa's-scarred by Portugal's colonial enterprise. ${ }^{8}$ By concentrating on the color as a product of the lighting, I do not disregard the fact that the characters' lives in the two films being analyzed hinge on this historical framework and on different levels of racial identity. On the contrary, aesthetics are associated with the experience of the Black subjects portrayed within. I take a perspective that dialogues with that of authors like Racquel Gates (2017) when she states, "Recognizing that aesthetic choices carry racialized politics requires acknowledging that the very process of filming is a political act." ${ }^{9}$

In order to develop my argument, I will divide the article into four sections. The first and most succinct section is dedicated to explaining the approach to the question of color. Second, I will develop the comparative analysis between Costa and Uchôa based on a common visual motif in In Vanda's Room and Seven Years in May: subjects wrapped in darkness and illuminated by fire during moments when they share their traumatic experiences. Third, I hope to strengthen the relationship between visual elements and memory by comparing Horse Money and Uchôa's film, with an emphasis on the potentials I hope to demonstrate how the film of spatial darkness to engender distinct temporalities in the image. I will conclude the article with a brief commentary, expanding on the main theme: the possible effects of aesthetic choices in the films for the viewer. Ultimately this article will contribute to the debate on the potential of color to modulate space-time in realist films in contemporary world cinema, and also, through a comparative approach, to the scholarship on the works of Pedro Costa and Affonso Uchôa.

\section{Notes on the color black}

Until now I have referred to black as a color. There is not a consensus on this, however. Throughout Western history, philosophers, scientists and artists have diverged on the identity of the color black. ${ }^{10}$ The source of the controversy is that depending on the system adopted to define colors, black may or may not be classified as a color. From the perspective of physics, one way of defining color is to consider it to be a phenomenon depending on the radiation of visible light-whose spectrum is composed of the colors red, orange, yellow, green, blue, indigo and violet. The color that reaches human eyes is the result of how the wavelengths of light are absorbed or reflected by an object. In this case, black is not considered a color because it is the result of an absence of visible light waves and, thus, color. In contrast, when the color is defined in terms of pigment, black is "what you get when all the primary colours are present equally in the mix. It is what you get when there is equality among colours" (Sexton 2017, 5). From this point of view, it is conventionally considered the sum of all colors. ${ }^{11}$

In this article the focus is on the color black as a phenomenon resulting from the partial absence of light. Why, then, is it considered a color? The reason is because Costa and Uchôa 
confer a pictorial quality upon it, transforming it into an element of visual composition and using it as a medium to form images. With its dark tones, the black that comes from the shadows and the night is used as a pigment on the screen, directly participating in the conception and the expressiveness of the spaces; this functions in a similar way to paintings made with a dark and nocturnal palette, such as NO-OD for Me (2008) and Painting for My Dad (2011)

by Noah Davis. In these terms, and despite being produced by darkness, black acquires, aesthetically, an effect of color. In addition, as previously stated, the spatial use of the color black by Costa and Uchôa is a visual shape connected to the social and subjective experience of Black people, playing on a resonance between the aesthetics of the image and the color as an affirmation of racial identity.

As regards the meaning of the color black, I should add that the perspective taken throughout this essay is aligned with an understanding that has reached a reasonable consensus in film studies. I am referring to the refusal to understand color, including black, as possessing a function or meaning, or as having emotional intelligibility prior to the existence of the work, in other words, as possessing fixed symbolism. Film scholars have for some decades been alert to the countless variables that contribute to the versatility of color, from its perception in everyday life to aesthetic uses (Everett 2007b). In this sense, Sergei Eisenstein's (1957, 150) defense is widely known, that color values and meanings are multiple and may assume contradictory positions: "In art it is not the absolute relationships that are decisive, but those arbitrary relationships within a system of images dictated by the particular work of art." From this perspective, each film builds its own "figurative economy" (Brenez 1998, 12, my translation), requiring the scholar to pay attention to the specific context in which colors are used-the work itself, as well as the technical, historical, cultural, and social conditions in which it is produced. The method employed, naturally, will depend on which aspects of the color are being investigated. In this article, although there is (also) an interest in its political effects, the analysis of color black will be based on aesthetic criteria. Wendy Everett $(2007 a, 111)$ gives us the precise analytical possibilities of such an approach: "The critic must therefore notice precise details, such as the various shades or nuances of colour that are used, the overall tonal range established by the film, the chromatic harmonies, dissonances, and modulations that structure the work, and the point in the narrative at which particular colours appear [...] Moreover, it is, of course, essential to establish how the colour relates to, and interacts with, other filmic signifiers."

\section{A flame in the darkness}

Costa's and Uchôa's films confront an issue that Jacques Aumont, in an essay entitled "Noirs," attributes to the filmic medium itself with regards to turning black into an essential color and not merely a chromatic quality of things: despite the effort to manipulate it as a matter of artistic expression, it is quite possible that the film image as "a victim of its photographic inclination" (Aumont 2009, 117, my translation) can lead to considering black as part of the world represented by vast shaded surfaces. Despite this, some films are able to transit from the black that chromatically qualifies certain objects to the black of an abstract background, and, thus, produce a figure that belongs to the material of the filmic medium. Aumont identifies these characteristics in cinematographic expressionism as well as in works by Stan Brakhage and Peter Goldman, among others. As his analysis suggests, the autonomy of the color black increases inasmuch 
as it dissociates from a figurative value and is confused with the filmic material itself, interfering with or referring to the properties of the film.

In the cases of Costa and Uchôa, the qualities of the color black must be thought of initially in relation to the prominent realist aesthetic in the use of long takes, real locations, and nonprofessional actors; individuals that act out their own experiences or others directly related to the communities to which they belong. On account of such choices, the viewer might be led to ask: is the black of the night and shadows only a chromatic quality of what is being filmed? Or does it address a visual element present there with the purpose of producing some other type of meaning? As I hope to justify going forward, the darkness that dominates the represented spaces creates an indistinctness, contributing to a constant and fluid transition between

the three-dimensional represented space and a territory of heterogeneous temporalities, between the present and the traumas of the past.

In In Vanda's Room, Pedro Costa depicts the daily life of residents, most of whom are Cape Verdean immigrants, in the old neighborhood of Fontainhas, on the outskirts of Lisbon. The film focus on gatherings and dialogues among the residents Vanda, her sister Zita, Nhurro, Paulo Muletas and Russo. Although these are occasions for affection and togetherness, their gatherings are equally dedicated to the use of drugs. There is no diegetic explanation for this, but it can be inferred that drug use is directly linked to the socioeconomic environment of the residents, who live in impoverish conditions, with no prospects for a better life. When Costa shot the film, using a small video camera (Panasonic DVX-100) that he operated himself, the neighborhood was in the process of being torn down by order of the Lisbon city council, and the residents were gradually leaving their houses.

Throughout In Vanda's Room, there is a predominance of dense masses of shadow that extend through the small rooms of the neighborhood's residents. The darkness appears to take on a specific meaning in scenes when the character Nhurro meets up with other residents to drink, talk, and do drugs, generally at night. When the meetings occur during the day, they happen inside Nhurro's house, with doors and windows shut. In these scenes, the only or main source of light comes from candles (Fig. 1), whose flame is insufficient to dispel the darkness. Without a source of lighting to supplement the candles, and since it was shot on a small DV camera, the image of these scenes is not very sharp. Little can be seen. It is important to highlight that these meetings are occasions to share sad and atrocious experiences for the residents of Fontainhas: times when they slept in shelters that were criminally set afire; incidents when they were robbed, even when they had little more than a few coins in their pocket; the failure of people to give them change; the fear of dying in poverty.

In the described scenes the predominance of the darkness covering the space makes it difficult to name who is speaking. The figures of the subjects dissolve into the shadows. The low visibility of the image directs our attention to the residents' stories. Traces of their bodies and the sound of voices saunter through the shot and occupy it with a ghostly presence. The integrity of the human figure "disappears on behalf of the collective presence, framed by the visual horizontality of the darkness [...]. A dark veil wraps the figures together into one, visually recreating the shared experience" (Costa Júnior 2020a, 277). In contrast to the demolition of the neighborhood, the voices and experiences of the Fontainhas residents signify a means of survival through 


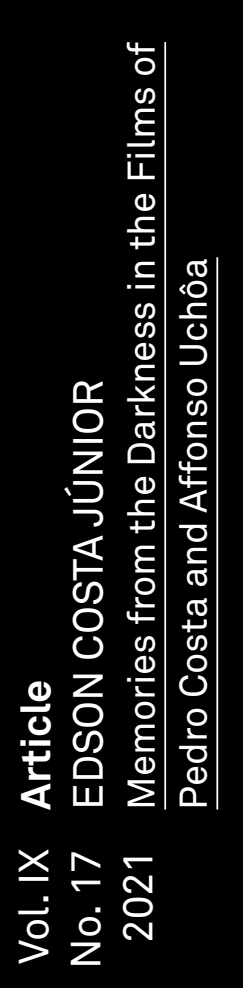

Fig. 1: In Vanda's Room (Pedro Costa, 2000) 
oral memory, preserved in film like a document for posterity's sake. Coming from people who fight to survive-at the same time that they destroy their own bodies through drugs - the narratives shared under darkness acquire an air of testimony. At least, a testimony in the sense of the Latin word superstes, which refers both to the survivor of a misfortune, or death, and to the person who witnesses a fact (Benveniste 2016).

Seven Years in May, directed by Affonso Uchôa, also draws on the visual motif of a flame in the darkness. Before discussing the work, it is necessary to understand its political purpose, for, as with Costa, nothing is merely a question of aesthetics. The film concentrates on the real testimony of a marginalized youth from the city of Contagem in the Brazilian state of Minas Gerais, who was tortured by the police after being mistaken for a drug trafficker. Rafael dos Santos Rocha,

a young Black man, returned home from work and was surprised by two vehicles. The police said they were there to investigate a complaint that there were drugs buried in his backyard. They entered his house, searched the rooms, and destroyed objects and furniture. Without finding anything, they took Rafael to a field, where they punched and kicked him repeatedly, asphyxiated him with a bag over his head, hanged him, cut his mouth with a revolver, burned his back with a lighter, and nearly killed him. They threatened to return to the youth's house a few days later to fetch 15,000 reais in drugs and money. Terrified, Rafael was forced to move to another city. His exile started with a trip to São Paulo, where he started using drugs, became a drug addict, and worked in a crack house and chop shops until he was arrested. Leaving prison, he continued his wanderings in Belo Horizonte, where he roamed the streets under the influence of crack until he returned to Contagem. Even today, says the youth, he dreams that the police will kill him.

In the film, Rafael gives his testimony in the same place where he was tortured. It lasts 17 minutes, in a fixed shot, with no cuts. Though the boy's testimony is the nucleus of the film's narrative, the work has four other sequences that are all filmed at night. The visual motif of a flame in the darkness is present in two of them: firstly, in the reenactment of the torture, which happens on a plot of land that is on fire (Fig. 2); and later, during the sequence of Rafael's testimony, when the youth tells his story sitting in front of a campfire that illuminates his face. At first glance, we notice a change between the two moments. The fervor and the threat of the flames during the reenactment that produces a hellish ambiance in the torture scene ${ }^{12}$ is substituted, during the testimony, by a temperate and intimate flame to which Rafael directs his gaze (Fig. 3, top). The dying fire seems to indicate a movement from the traumatic event to the memory of it, from the terror experienced to facing it, through the courage of giving testimony about it.

Another aspect to point out, specifically about the testimony scene, is that the flame in the darkness allows for self-contemplation, an internal gaze protected from the world..$^{13}$ Similar to In Vanda's Room, the low lighting creates an ambiance favorable to the reflection and sharing of memories. In this sense, it is possible to recount Aumont's commentary about the films of Godard, Alexander Sokurov and Bill Viola in which the refuge in the darkness is a "condition of meditation, rest, and reappropriation of the self. Inhabited, the shadow is a metaphor, even while it is experienced, of poetry. In it, the time necessary for thinking can be experienced" (Aumont 2012, 119 , my translation). In the case of Seven Years in May, contemplation is necessary to confront the trauma that was experienced, with the witness 
Fig. 2: Seven Years in May (Affonso Uchôa, 2019)

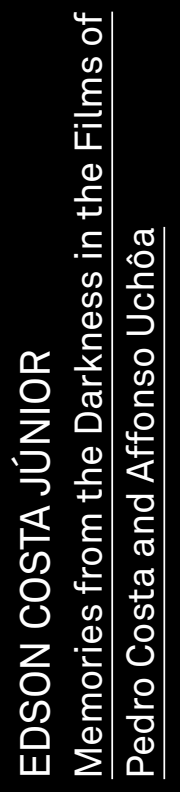

wist:

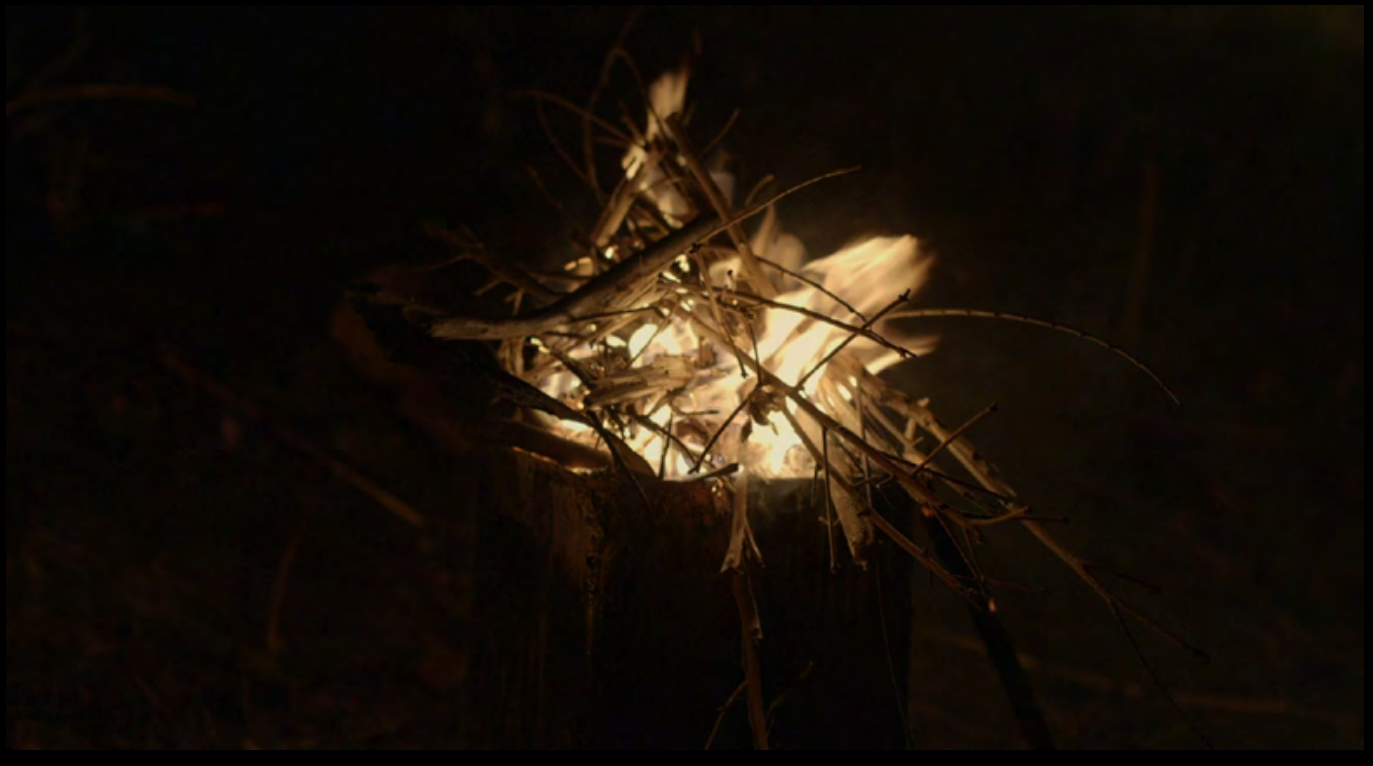

$x ㄷ$

के 
assigning it a shape. At the same time, darkness is also a condition of the clandestine. According to Leandro and Araújo (2020), Uchôa's filming in the dead of night goes back to the furtiveness imposed on the testimonies of young Black and poor Brazilians, who, when denouncing the violence suffered, are in danger of disappearing by execution or imprisonment.

While in the analyzed scenes from In Vanda's Room, darkness creates conditions for the representation of a collective experience, in Seven Years in May the narration of Rafael's torture takes place in a dialogue with another young Black man who is poor and also a victim of police violence (Fig. 3 , bottom). He is a fictional character who, after listening to Rafael, says: "I have been through so much that almost every story I hear seems to be mine." Through dialogue, the real experience of torture is amplified, and it is no longer an individual injustice. It acquires a collective scope, presenting itself as part of the current genocide of the Black and poor population in the peripheries of Brazil taking place at the hands of the State. ${ }^{14}$

\section{A territory between times}

While the visual motif of the flame in the darkness allows a first approach to the connection between the space dominated by the color black and the memories of the filmed subjects, Horse Money and Seven Years in May use the spatial shadows to develop an elasticity in the represented space, converting it into a means of welcoming heterogeneous temporalities.

In Horse Money, the narrative structure is marked by pendular movements, a constant coming and going between historical times. At the core of this movement is the character Ventura, a Cape Verdean whose presence is assailed by the memories of 11 March 1975, in Portugal, when
General António de Spínola attempted a coup d'etat. The film explores the tension between the country's official history and the Black immigrants' experience of it, or between the memory of the former and the forgetfulness of the latter. The narrative centers on the Cape Verdean perspective. While a part of the Portuguese population experienced the consequences of 11 March, Ventura, Vitalina, and other immigrants from the former Portuguese colony have suffered the cruelty of daily life, surrounded by poverty and socio-racial inequality. In the film they appear in underground tunnels (Fig. 4, top), hospitals, abandoned factories, dark rooms, and deep nights (Fig. 4, bottom), recalling unhappy memories, such as the wife who traveled from Cape Verde to Portugal to bury her husband; workers who have been waiting for payment for decades; and victims of fatal or deeply scarring work accidents. Horse Money is devoted to these stories and the individuals who carry them (see Costa Júnior 2020b, 13).

The shadows in space define one territory or, in fact, two: the light and the dark. The strong contrast separates the two poles into two worlds (Fig. 5). The shot is fragmented when it is cut by the lines and shapes. The dark tones reinforce the mourning in the immigrants' reports. At the same time it drags haunted areas and the traumas of the past into the present. The conversion of a represented space into a remembered time is associated with the composition of dark masses in the shot. They take on the appearance of abstract shapes or pure surfaces of color that slip away from the recognizable three-dimensional space, creating an unknown territory.

In order to corroborate the existence of a territory of remembrance, we can recall the function of shadows in the work of an influential figure for Costa: Jacques Tourneur. ${ }^{15}$ The French filmmaker's collaborators, as well as 



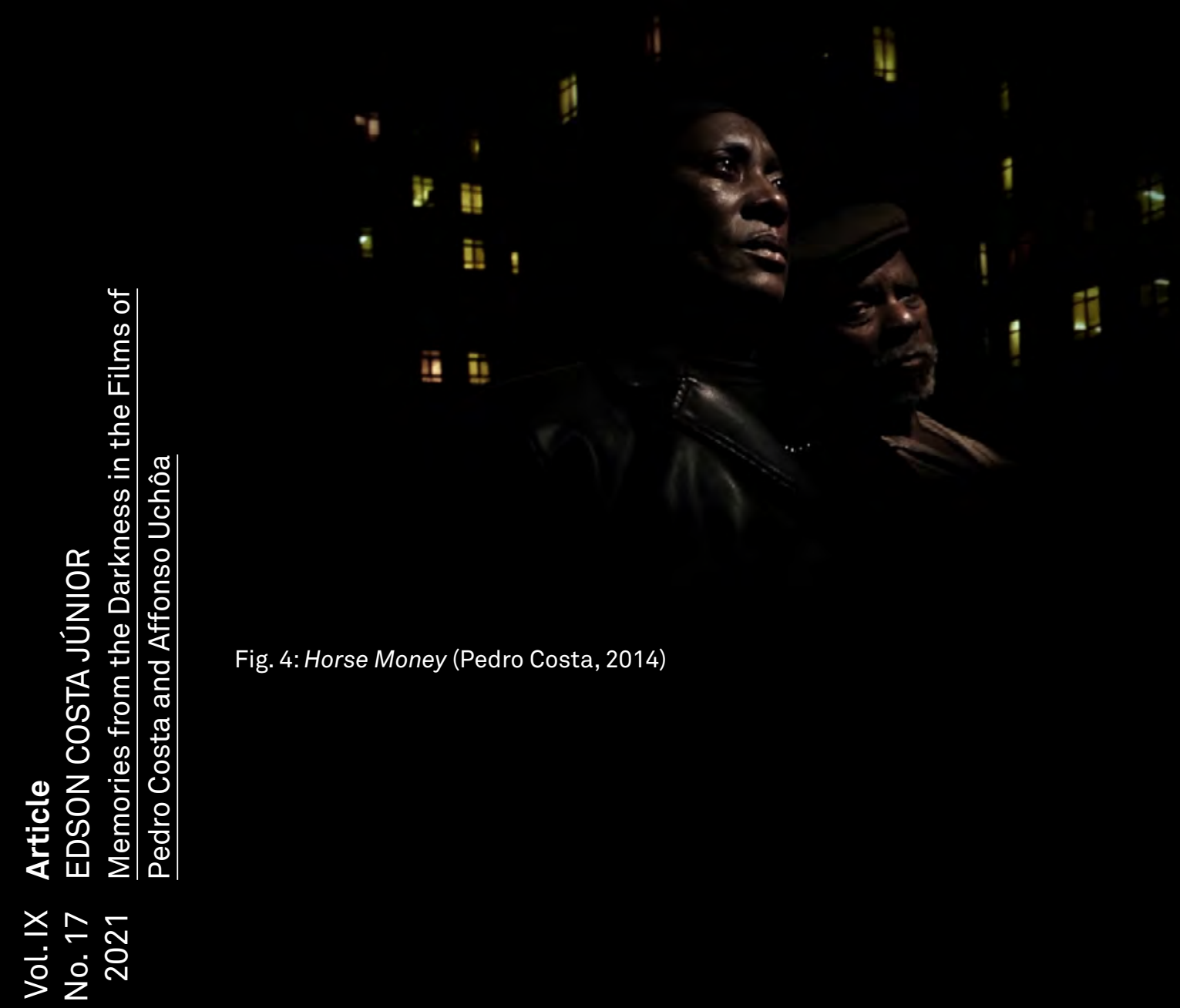


scholars devoted to the study of his work, have frequently emphasized the importance of twilight in creating a particular atmosphere in his films. Three testimonies, gathered by Chris Fujiwara $(1998,74)$, deserve to be highlighted: 1. Producer Val Lewton's remark: "If you make the screen dark enough, the mind's eye will read anything into it you want!"; 2. Paul Willemen's distinction of the presence of a dark area in the foreground of shots that have contributed to the essential structure of fantasy in Tourneur's work; 3. J.P. Telotte's understanding of dark patches as void of meaning in the physical realm, a space that is irreducible to the viewer's natural desire to fill it with consciousness and significance.

The three comments on Tourneur are close to what Aumont (2012, 98, my translation) calls "the shadow as a medium," that is, a formal, figurative, and even figural operator. More than a denial of light, the dark environment is as much a part of our daily experience as it is a poetic power: "The twilight is a world apart, which has a rationality and, above all, another value. It is not so much the opposite of the luminous world than it is a completely different world. [...] The shadow world [...] has its own time, its own resonance, its particular ways of being inhabited and its privileged human actions" (Aumont 2012, 124, my translation).

This power of the shadows also exists in Horse Money. In his shots divided between light and darkness, the color black infiltrates the domain of other times, the memory of a traumatic past, in the realist representation. The subject in the image simultaneously inhabits the present and the layers of memory; as is suggestively indicated, for example, in the duplication of Vitalina's body from her projected shadow in the shot of her arrival (Fig. 5 , bottom). Such a reading, of course, takes into consideration the verbal remembrance through the Black immigrants' speeches, the appearance in abandoned spaces linked to their cruel life histories, and, also, the very editing of the film, in its constant coming and going between times. Color allows this intertemporal dynamic to happen within the shot itself, visually.

As in Costa's film, I believe that the possibility of the use of multiple temporalities, born from the color black, can be seen in Seven Years in May. In this case, night takes on this intention. While during the filming process some scenes were shot in the daytime (Barbi 2021), the final cut exclusively features night takes. There are various possible reasons for this choice. Earlier we mentioned Leandro and Araújo's (2020) hypothesis that darkness offers a clandestineness necessary for the testimony. Another reason, given in the diegesis of the film itself by the fictional character (Fig. 3 , bottom) who talks with Rafael, is to make a reference to the genocide of Black and poor people in Brazil: "There are many people dying every day. We are surrounded by a pile of dead people, bro. And that pile is only growing, since before we were born. And it's so tall it capped the sky. That's why everything is so dark." Here I would like to follow the more obvious hypothesis that the exclusiveness of the night directly refers to Rafael's memories, including those of his torture. In this sense, the spaces in the film allow for, through the darkness, the constant commute between the present and the past.

The first indication of the association comes from the film's opening scene, when Rafael, backlit, appears walking on a deserted street. He comes from the background of the image to the foreground, crossing zones of light and shadow created by the flashing of the streetlights (Fig. 6). In the end, darkness enters, when the figure and space, the subject and the night, become one. The montage makes this 


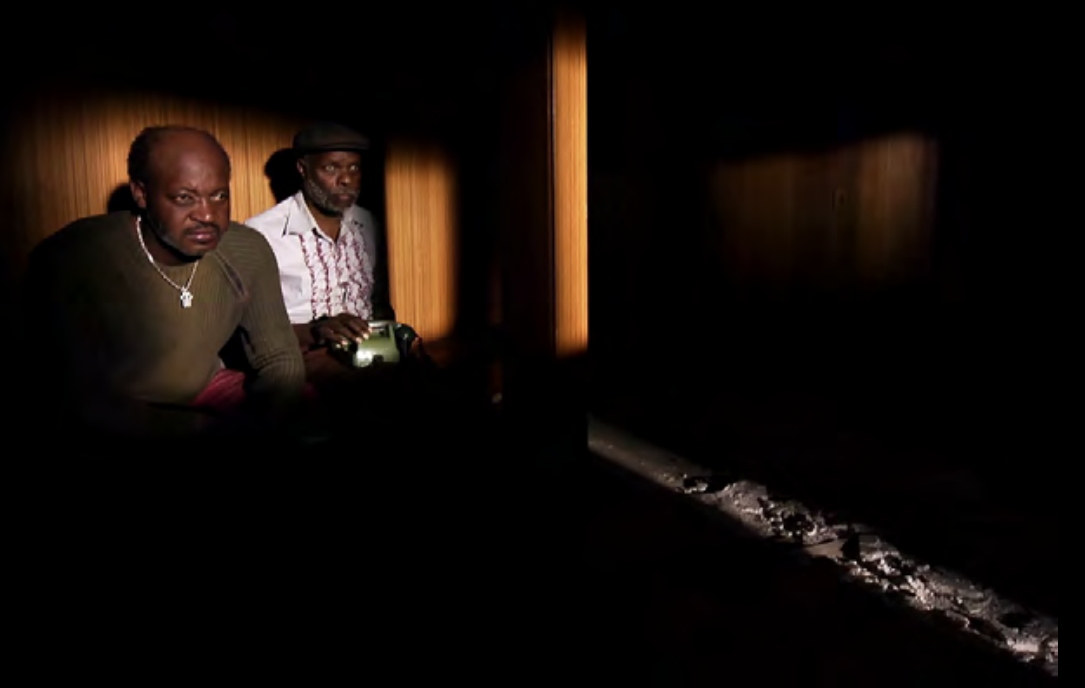

Fig. 5: Horse Money (Pedro Costa, 2014)

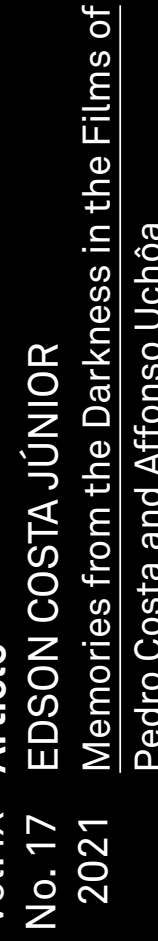

Fig. 6: Seven Years in May (Affonso Uchôa, 2019) 
scene a passage into memory, as the following shot shows a reenactment of torture, materializing the past, although without the intention of exhausting it or of faithfully or objectively reproducing it. In fact, the reenactment develops reflexively: in the beginning, friends of Rafael, dwellers from Contagem, dress up as policemen in front of the camera while commenting on the clothes and the role they will play. Like Rafael's verbal testimony, it is one of the film's other ways of narrating the past and confronting it with fiction.

The plurality of perspectives adopted to tell Rafael's story seems to take into account the way traumatic events resist representation, or the survivors' difficulty in providing a narrative form, in line with the terror experienced. ${ }^{16}$ In the face of that which is resistant to symbolization, fiction becomes a power to be explored. Seen in this way, the predominance of the color black in the film, due to the predominance of shadows and nighttime, can be justified as one of the signs of the poetically/fictionally revised past, an occasional fragment of torture that spreads through and infects the present. The film images suggest this fluidity or migration of elements, spaces, and temporalities; one example is the fire in the torture and testimony scenes, as discussed above.

In the conditions analyzed above, the trauma narrative, through Rafael's speech and the filmic form, renounces a fixed past that is reproduced with accuracy and clarity; but rather it opts to access memory as a dark pocket, without safe beacons, as a medium open to fiction and rewriting. While in cinema "the entrance into the shadows always carries a risk of getting lost at the very least, and, generally, it means death" (Aumont 2012, 111, my translation), in Seven Years in May the passage through the darkness at the beginning of the film is a crossing, not without danger-given the return to the wound opened by the trauma-to the territory of memory. In this way, Rafael's testimony is not inscribed on the white page of a judicial document, but in the dark tones of the night.

\section{A means of sharing}

We have seen that the films analyzed here present narratives directed towards sharing the social experiences of Black and marginalized subjects. About Horse Money, Costa (2014) says that when he searched the Portuguese newspaper archives of 1975 about the protests against the coup d'état that occurred that year, he did not find a single Black face in the photographs. While a part of Portugal fought against the military forces, Cape Verdean (like Ventura), Angolan and other immigrants were distressed, worried about job security, if they would be able to save enough to bring their wives and children from their homelands, if they would be deported. Seven Years in May is about hearing a testimony that refers both to Rafael's past and to the present state of the Brazilian Black and marginalized population that continues to be exterminated (Cerqueira et al 2020), while the current federal government denies the existence of racism in the country (Cabral 2020). Considering the cited conditions, both Horse Money and Seven Years in May are opposed to forgetting the experience of sociohistorical subjects through the official written history. As I have demonstrated, the color black is directly involved in this political function.

Besides directly contributing to the modulation of filmic spacetime according to the memories and testimonies of the filmed subjects, the color also promotes the communication between the diegetic universe and the viewer's space. I am referring to the effect caused by the predominance of darkness that softens the edges of the filmic frame, the "frame-object" 
(Aumont 2004, 118, my translation) that makes the cinema screen a separate space, a window that distinguishes the world of the film from that of the viewer. Thus, the color black blurs the limits, creates a zone of continuity (not homogeneous, given the different shades) between the diegetic universe and the place where the work is being shown, making one an extension of the other. ${ }^{17}$ The darkness of the theatre no longer provides a safe distance between the spectator and what is in the image, ${ }^{18}$ but it becomes the means of communication between the two poles. Sharing the darkness strengthens the reach of the subjects' experiences filmed by Costa and Uchôa, making their words and experiences resonate with the viewer and returning them to their place of origin: real life.

Translated by Alisa Wilhelm

1/ I cite Bazin's (2014) well-known quote describing one of the scenes in Umberto D (1952) by Vittorio De Sica.

2/ Through a distinct approach, Asian filmmakers like Malaysian/Taiwanese Tsai Mingliang and Thai Apichatpong Weerasethakul cross the present time with dimensions from the past in their films. In spite of the emphasis on daily life and the aesthetic methods commonly associated with realism, the coexistence of ghosts, spirits, and living people is common in their works. In accordance with religious traditions like Buddhism, Taoism and animism in their lack of separation between the spiritual and material worlds (Mello 2015), their films allow for the interaction of different timelines and ontological realms of being.

3/ In The Movement-Image, the name was mistakenly written as Pascal Augé (Auger 2011). Some researchers took the confusion even further, believing it to be a mention by Deleuze to Marc Augé and the concept of non place (non lieux).

4/ Although Deleuze recognizes that both the darkness of expressionism and the white of lyrical abstraction perform, in certain aspects, the role of colors, he chooses not to discuss them as such.

5/ Night and darkness respond to different political questions in this filmography. Dazed Flesh, which the Black filmmaker Grace Passô directs and stars in, questions the socioracial identity as something under constant construction. Republic, filmed during the COVID-19 quarantine, is based on the despair and incredulity of living in Brazil, in which life, especially that of poor and Black people, has no value to the state. Finally, Tell This... and Tremor lê respond, through documentary and speculative fiction respectively, to the troubled Brazilian political landscape of recent years, especially after the 2016 parliamentary coup that deposed the then-president Dilma Rousseff.

6/ Although I'm considering Affonso Uchôa as white, it would be important to know the racial self-declaration. The criteria of racial categories in Brazil are often controversial because of interracial mixing within the Brazilian population. In the country, for instance, race depends on appearance, ancestry and even socioeconomic factors.

7/ Recognizing the political value of language in defining the place of an identity, Kilomba (2019) opts to use the term Black, written with a capital "B", to refer to people and a political identity. Throughout this article I will use Black in this sense, and reserve black with a lowercase " $b$ " to refer to the color as an aesthetic element produced by light.

8/ About the Atlantic slave trade, which extended from the 15th to the 19th centuriesand which Portugal benefited from with its colonialism - Mbembe $(2017,2)$ writes that "men and women from Africa were transformed into human-objects, human-commodities, human-money. Imprisoned in the dungeon of appearance, they came to belong to others who hated them. They were deprived of their own names and their own languages. Their lives and their work were from then on controlled by the others with whom they were condemned to live, and who denied them recognition as cohumans. And yet they nevertheless remained active subjects."

9/ The author discusses the priority typically given by the cinema industry to the beautification of white skin on the screen, with lighting and color set-ups and technologies designed to optimize it, while they were incapable of capturing the nuances of darker skin tones. It was because of this, Gates remembers, that at the end of the 1970s Jean-Luc 
Godard criticized the Kodak film stock as inherently racist, refusing to use it in his works. 10/ Its status as a color was denied, for example, in A Treatise on Painting by Leonardo da Vinci in the 15th century, in Isaac Newton's color spectrum in the 17th century, and by artists such as Paul Gauguin (Pastoureau 2008) and Ad Reinhardt, for whom "black is interesting not as colour but as noncolour and as the absence of colour" (artscanada 1967,3).

11/ Beyond the physical properties that define the color black, it must be recognized as a matter of perception and interpretation, as with the other colors: "Far from being a straightforward property of the objects around us, colour is, in reality, both a physical characteristic of light and pigment and a psychological and physical sensation, both an objective and a subjective phenomenon" (Everett 2007b, 10).

12/ The director of photography for the film, Lucas Barbi, stated that the presence of flames in the reenactment of the torture happened by accident. The film crew went to the locations when they saw a fire burning a plot of land. At that moment, they decided to get the actors and go there to film the scene. Everything was very quick, before the fire went out (Barbi 2021).

13/ In the history of European art, this quality is present, for example, in the paintings of Georges La Tour where the presence of a flame evokes a protection from the darkness, blocking out the outside world and forming a refuge created by the respite of a flickering flame (Milner 2005).

14/ In 2018,75.7\% of homicide victims in Brazil were Black. In addition, from 2008 to 2018, the number of homicides among this group increased by $11.5 \%$, while among non-Black people it dropped by $12.9 \%$ (Cerqueira et al 2020).

15/ As Costa (2009) admits, the initial script for his feature film Down to Earth (Casa de Lava, 1994) was a remake of I Walked with a Zombie (Tourneur, 1943).

16/ I am basing this on Seligmann-Silva's (2003) reflection on the literature of testimony, a field with which Uchôa's film, I believe, maintains strong affinities.

17/ Even seen at home, the films discussed here require darkness as a display device. Otherwise, the brightness can substantially alter the black tones in the image.

18/ As was believed by authors associated with the psychoanalytic-semiological paradigm, according to which darkness was the basis of a scopic regime, as it separated the spectator-voyeur and the object of the gaze. According to Metz $(1982,64)$, for example, "[...] the obscurity surrounding the onlooker, the aperture of the screen with its inevitable keyhole effect" directly contributed to scopophilia.

\section{References}

artscanada. 1967. "Black" Issue, 113, October.

Auger, Pascal. 2011. "Entretien avec Pascal Auger: autor de Deluze et du cinéma." Interview by Nicolas Rousseau. Actu Philosophia, 11 July. http://www. actu-philosophia.com/entretien-avec-pascal-auger-autour-de-deleuze-et/ [accessed March 2, 2021]

Aumont, Jacques. 2012. Le montreur d'ombre: essai sur le cinéma. Paris: J.VRIN. 2004. O olho interminável. Translated by Eloisa Araújo Ribeiro. São Paulo: Cosac Naify.

2009. Matière d'images, redux. Paris: Éditions de la Différence.

Barbi, Lucas. 2021. Unpublished interview with Edson Pereira da Costa Júnior, July.

Bazin, André. 2014. 0 que é o cinema? Translated by Eloisa Araújo Ribeiro. São Paulo: Cosac Naify.

Benveniste, Émile. 2016. Dictionary of Indo-European Language and Society. Translated by Elizabeth Palmer. Chicago: Hau Books.

Brenez, Nicole. 1998. De la figure en général et du corps en particulier: L'invention figurative au cinéma. Paris, Brussels: De Boeck Université. 
Cabral, Marcelo. 2020. "Bolsonaro ignora impacto do caso Carrefour e segue negando racismo no Brasil." El País, 22 November.

Cerqueira, Daniel; Samira Bueno, Paloma Palmieri Alves, Renato Sergio de Lima, Enid R.A. da Silva, Helder Ferreira, Amanda Pimentel et al. 2020. Atlas da violência. Instituto de Pesquisa Econômica Aplicada, Ministério da Economia, Governo Federal - Brasil. https://dx.doi.org/10.38116/riatlasdaviolencia2020

Costa, Pedro. 2009. "Crossing the threshold." Interview by Kieron Corless. Sight \& Sound, October. http://old.bfi.org.uk/sightandsound/feature/49569 [accessed October 24, 2021]

. 2014. "Murmures dans un corridor lointain." Interview by Miguel Armas. Lumière, October.

Costa, João Bénard da. 2019. "O Negro É Uma Cor ou o Cinema de Pedro Costa." In Cem Mil Cigarros, edited by Ricardo Matos Cabo, 16-28. Lisboa: Orfeu Negro.

Costa Júnior, Edson Pereira da. 2020a. "A comunidade na expropriação: modos de alteridade no cinema de Pedro Costa." MATRIZes 14(1): 267-88. https://doi. org/10.11606/issn.1982-8160.v14i1p267-288

2020b. "A fotografia e a política das imagens em Pedro Costa." Anais do XXIX Encontro Anual da Compós. Campo Grande: UFMS/Compós.

Deleuze, Gilles. 1986. Cinema 1 - The Movement-Image. Translated by Hugh Tomlinson and Barbara Habberjam. Minneapolis: University of Minnesota Press.

Eisenstein, Sergei. 1957. The Film Sense. Edited and translated by Jay Leyda. New York: Meridian Books.

Elsaesser, Thomas. 2009. "World Cinema: Realism, Evidence, Presence." In Realism and the Audiovisual Media, edited by Lúcia Nagib and Cecília Mello, 3-19. New York: Palgrave Macmillan.

Everett, Wendy. 2007a. "Colour as Space and Time: Alternative Visions in European Film." In Questions of Colour in Cinema: From Paintbrush to Pixel, edited by Wendy Everett, 105-26. Oxford, New York: Peter Lang.

.2007b. "Mapping Colour: An Introduction to the Theories and Practices of Colour." In Questions of Colour in Cinema: From Paintbrush to Pixel, edited by Wendy Everett, 7-38, Oxford, New York: Peter Lang.

Fujiwara, Chris. 1998. Jacques Tourneur: The Cinema of Nightfall. Jefferson, North Carolina: McFarland \& Company.

Gates, Racquel. 2017. "The Last Shall Be First: Aesthetics and Politics in Black Film and Media." Film Quarterly, 71(2): 38-45. https://doi.org/10.1525/ FQ.2017.71.2.38

Kilomba, Grada. 2019. Memórias da Plantação: Episódios de Racismo Cotidiano. Translated by Jess Oliveira. Rio de Janeiro: Cobogó.

Leandro, Anita, and Mateus Aráujo. 2020. "Torturadores e torturados: a violência de Estado em dois filmes brasileiros recentes." Doc On-line, 28: 40-63. https://doi. org/10.25768/20.04.02.28.03

Mbembe, Achille. 2017. Critique of Black Reason. Translated by Laurent Dubois. Durham and London: Duke University Press. 
Mello, Cecília. 2015. "O cinema contemporâneo do leste asiático: da ontologia e seus fantasmas." In Realismo fantasmagórico, edited by Cecília Mello, 15-33. São Paulo: USP.

Metz, Christian. 1982. Psychoanalysis and Cinema: The Imaginary Signifier. Translated by Celia Britton et al. London/Basingstoke: The Macmillan Press.

Milner, Max. 2005. L'envers du visible: essai sur l'ombre. Paris: Éditions du seuil.

Pastoureau, Michel. 2008. Black: The History of a Color. New Jersey: Princeton University Press.

Seligmann-Silva, Márcio. 2003. "O testemunho: entre a ficção e o real." In História, memória, literatura: o testemunho na era das catástrofes, edited by Márcio Seligmann-Silva, 371-85. Campinas: Editora Unicamp.

Sexton, Jared. 2017. "All Black Everything." e-flux 79:1-12.

Simões, Leonardo. 2015. “Diálogo de Luz e Sombra." Filmed June 2015 in Porto Iracema das Artes, Fortaleza, Brazil. https://www.youtube.com/ watch?v=5aePfHQoX3g [accessed March 15, 2021]

Uchôa, Affonso. 2020. "A periferia reimaginada." Interview by Maria Chiaretti and Mateus Araújo. Aniki, 7(2). https://doi.org/10.14591/aniki.v7n2.677 